\title{
Signs of Law: The Roberta Kevelson Seminar on Law and Semiotics at Penn State University's Dickinson School of Law
}

\author{
Jan M. Broekman • William A. Pencak
}

This Special Issue focuses on the confrontation of US Law School students with legal semiotics in the final period of their studies. Their experience, opinion and interest have hitherto never been documented. Here are the reports of thirteen Seminar students, presented in four categories: (1) personal experience, (2) the Seminar theme 'Signs of Law', (3) the Critical Power of Semiotics and (4) Semiotics in US Courtrooms. They are a unique material for the exploration of semiotics as an element of legal training.

The second Part of this Issue offers the two Prize-winning student essays: Harvill and Garrett. There are also two contributions to the Round Table, which took place in the course of the Seminar: a teleconferenced expose of A. Wagner and the closing address of Jan M. Broekman.

\footnotetext{
J. M. Broekman $(\bowtie)$

Dickinson School of Law, Penn State University, Carlisle, PA, USA

e-mail: jmb56@dsl.psu.edu

W. A. Pencak

Dpt History, Penn State University, University Park, PA, USA
} 